\title{
EFFECT OF TYPE OF REPLACEMENT FILL BENEATH STRIP FOOTING ON ITS BEHAVIOR
}

\author{
M. A. Mahmoud \\ Lecturer, Civil Engineering Department, Helwan University, Cairo, Egypt \\ Ahmed. S. Rashed \\ Lecturer, Civil Engineering Department, Higher Institute of Engineering, \\ El-Shorouk City, Cairo, Egypt \\ A. M. Radwan \\ Professor, Civil Engineering Department, Helwan University, Cairo, Egypt \\ A. Nasr \\ Assistant Lecturer, Civil Engineering Department, Tiba Institute, Cairo, Egypt
}

\begin{abstract}
The design of shallow foundations resting on replacement fill depends on the replacement deformation behavior. The fill is usually a compacted granular sandy or gravelly soil or a mix of them. The stiffness of the fill controls the deformation behavior of the footing, including strip footing. Two types of loading give equal final total load. The loads may comprise a series of point loads or a uniform line load. The type loading have a major role on the strip footing deformation behavior. The thicknesses of the footing have also a role on its performance. In recent years, finite element programs have been used to obtain the actual performance of the footing using the suitable soil model. In this study, an experimental work is performed to represent a loaded strip footing with a series of point loads and the settlement of the footing is recorded for different types of fill. Thereafter, an analytical model is performed and solved by non linear solution using PLAXIS 3D program. The models were performed to examine the effect of changing the type of loading. Results are compared with the experimental findings.
\end{abstract}

Keywords: Strip footing, Settlement, experimental work and Finite element analysis.

Cite this Article: M. A. Mahmoud, Ahmed. S. Rashed, A. M. Radwan and A. Nasr, Effect of Type of Replacement fill Beneath Strip Footing on its Behavior. International Journal of Civil Engineering and Technology, 11(1), 2020, 279-287.

http://iaeme.com/Home/issue/IJCIET?Volume=11\&Issue $=1$ 


\section{INTRODUCTION}

Evaluation of the settlement of shallow foundation is a fundamental objective in foundation engineering. This is due to the fact that the bearing capacity against shear failure of shallow foundation resting on granular soil has normally a large magnitude, which in turn makes the allowable settlement more suitable to control the overall design. Finite element programs are used in the design of structural element, which can get the values of displacement; however, there are differences between the calculated and measured values. Therefore, there is a great need to increase the credibility of the finite element programs by comparing their results with results obtained from the site or laboratory measurements.

A study carried out by Arnold (1980) [1] offered a method for estimating the settlement of shallow foundations on cohesion less soil based on calculating the relative density. The results of this method were compared with the results of published case histories. It was found that the ratio between the calculated settlement and the observed settlement is $73 \%$ of the cases, but at $50 \%$ of the cases, the ratio was between 0.67 and 1.50. Sivakugan et al (1998) [7] performed a comparison between those results and the settlement predicted by the Terzaghi and Peck method $(1948,1967)$ [8]. This comparison showed that there is a gap between the predicted settlements and the observed settlements. Kaggwa et al (2002) [5] noted that it was only through luck that particular deterministic prediction coincided with the observed settlement because of spatial soil variability. They concluded that the effect of variation of Young's models within soil profile on the predicted elastic settlement can be readily quantified in routine analysis. So, he suggested a statical producer that could be used to evaluate the likelihood that particular predicted settlement would be successful.

Hamdy (2004) [3] carried out a study to observe the behavior of beam on elastic foundations. The study was based on both laboratory experiments and theoretical study. She noted that to obtain realistic values for the settlement of strip footing from finite element programs, a compatible value for the modulus of subgrade reaction should be assessed.

\section{EXPERIMENTAL WORK}

\subsection{Types of Soil}

Different types of fill were used in this study. The tested soil samples were i) sand (A), ii) sand with gravel 1:1 (B), and iii) sand with gravel 1: 2 (C). Tests were carried out to determine the different properties of the used soils. Figure1 presents the grading curves for the different types of the used soil and Table1, presents the soil properties.

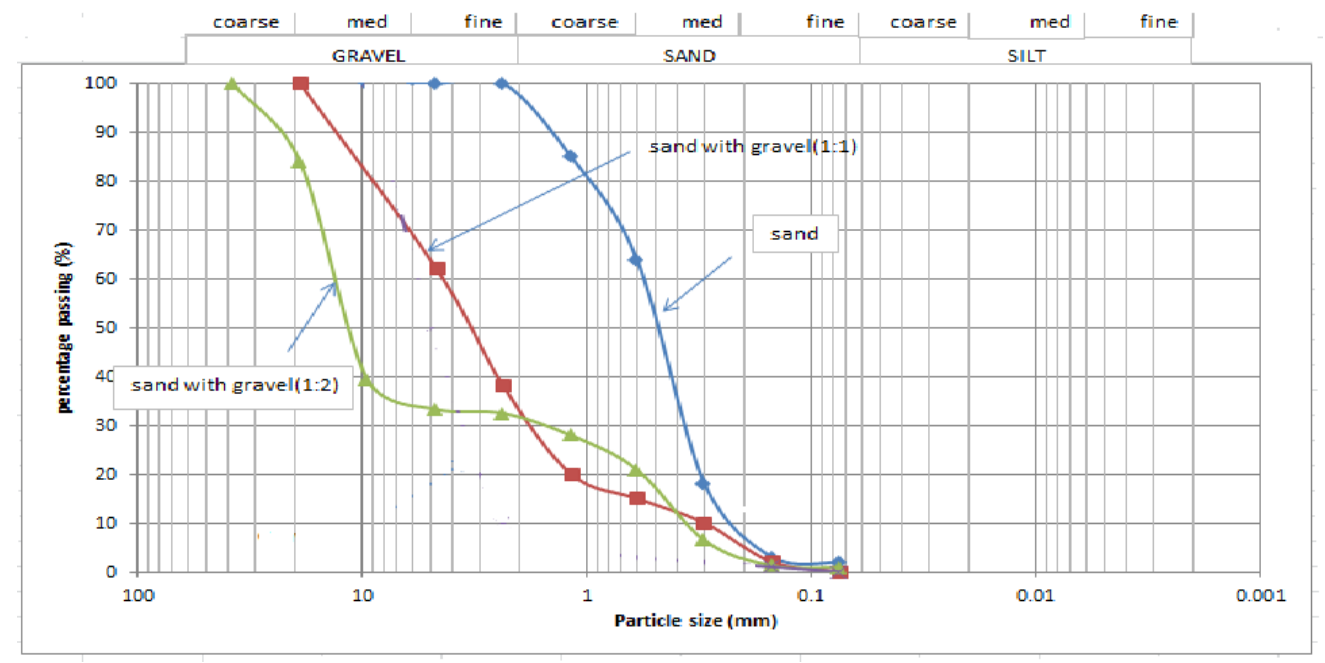

Figure 1 Grading curves for compacted fill 
Three samples were prepared in the laboratory for each soil type at relative densities equal to the relative densities used in the experiments. Using the oedometer compression test the constrained modulus was measured. So, the elastic modulus of the four used soils (E) could be calculated by using the relation proposed by Lambe and Whitman (1969) [6].

Table 1 Soil properties

\begin{tabular}{|l|c|c|c|}
\hline \multicolumn{1}{|c|}{ Property } & Type A & Type B & Type C \\
\hline D10 & 0.21 & 0.3 & 0.4 \\
\hline D30 & 0.38 & 1.9 & 1.5 \\
\hline D60 & 0.55 & 4 & 12.5 \\
\hline Uniform coefficient $\left(\mathrm{C}_{\mathrm{u}}\right)$ & 2.6 & 13.33 & 31.52 \\
\hline Curvature coefficient $\left(\mathrm{C}_{\mathrm{C}}\right)$ & 1.25 & 3 & 0.45 \\
\hline USCS system & $\mathrm{SP}$ & $\mathrm{SW}$ & $\mathrm{GP}$ \\
\hline the elastic modulus $(\mathrm{E})-\mathrm{kg} / \mathrm{cm}^{2}$ & 454.2 & 727.4 & 850 \\
\hline
\end{tabular}

\subsection{Model Tank}

The tank used for the model tests had a rectangular cross section of inside dimensions $120 \mathrm{~cm}$ long, $20 \mathrm{~cm}$ wide, $40 \mathrm{~cm}$ deep. Stiffeners of steel angles $50 \times 50 \times 5 \mathrm{~mm}$ were welded at equal spacing along the tank length. These were adopted to ensure the tanks rigidity and to decrease the deflection that may affect the results. The internal walls of the tank were coated with a thin film of paint before placing the sample. This was done to minimize the friction between the soil and the side walls of the tank. Static loads were applied through levers, as shown in Figure 2. Loads were transmitted to the strip footing model through a rod $16 \mathrm{~mm}$ diameter. The lever arm was used to apply loads to the rod. A weight hanger was hung in position on the lever arm, which was divided to scale the load by a ratio $1: 10$.

\subsection{The Strip Footing Model}

Three strip-footing models were made using Perspex elastic material. The models have the same length of $110 \mathrm{~cm}$ and $4 \mathrm{~cm}$ wide. Their thickness varied, being 8,10 and $12 \mathrm{~mm}$. The thickness of the strip was changed to simulate different rigidities of the foundation. Settlements at five points of the footing were measured, as shown in Figure 3. Each model was tested under a series of concentrated loads, the summation of loads was 40,60 and $80 \mathrm{~kg}$.

\subsection{Testing Program}

The experimental program included .7 tests. For each case, total load was taken 40, 60 and 80 $\mathrm{kg}$. These tests were performed in order to verify the behavior of the strip footing in the different cases in the experimental models, Table2, presents the parameters of the testing program. 


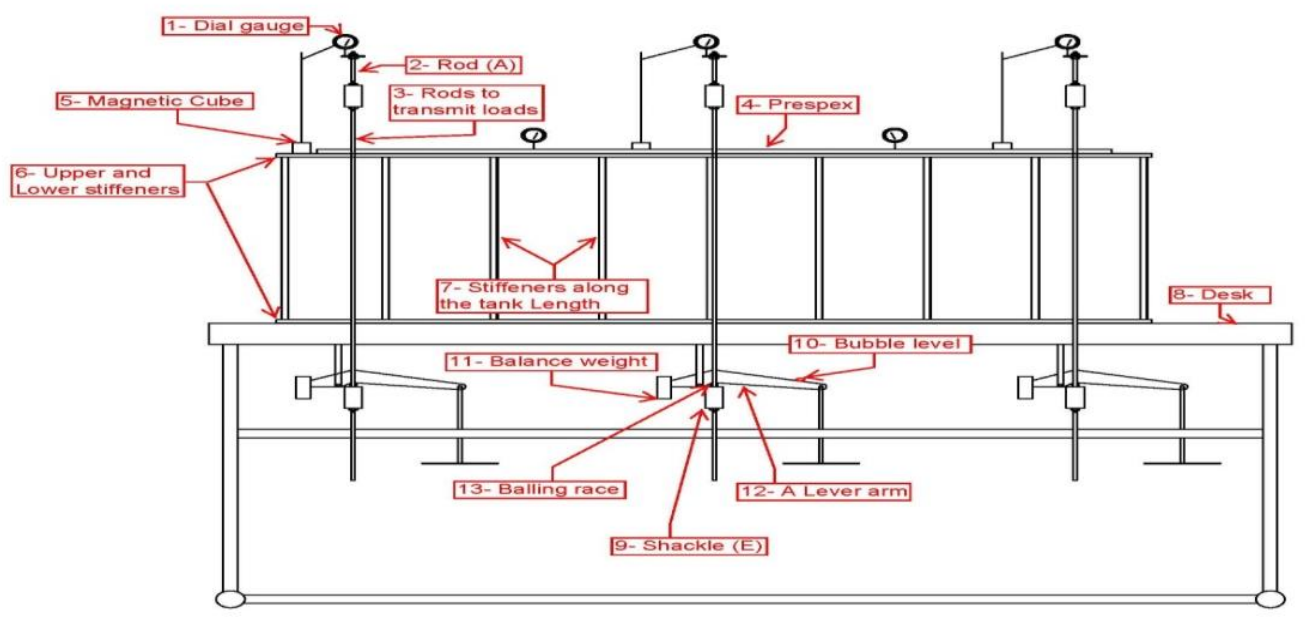

Figure 2 Loading system
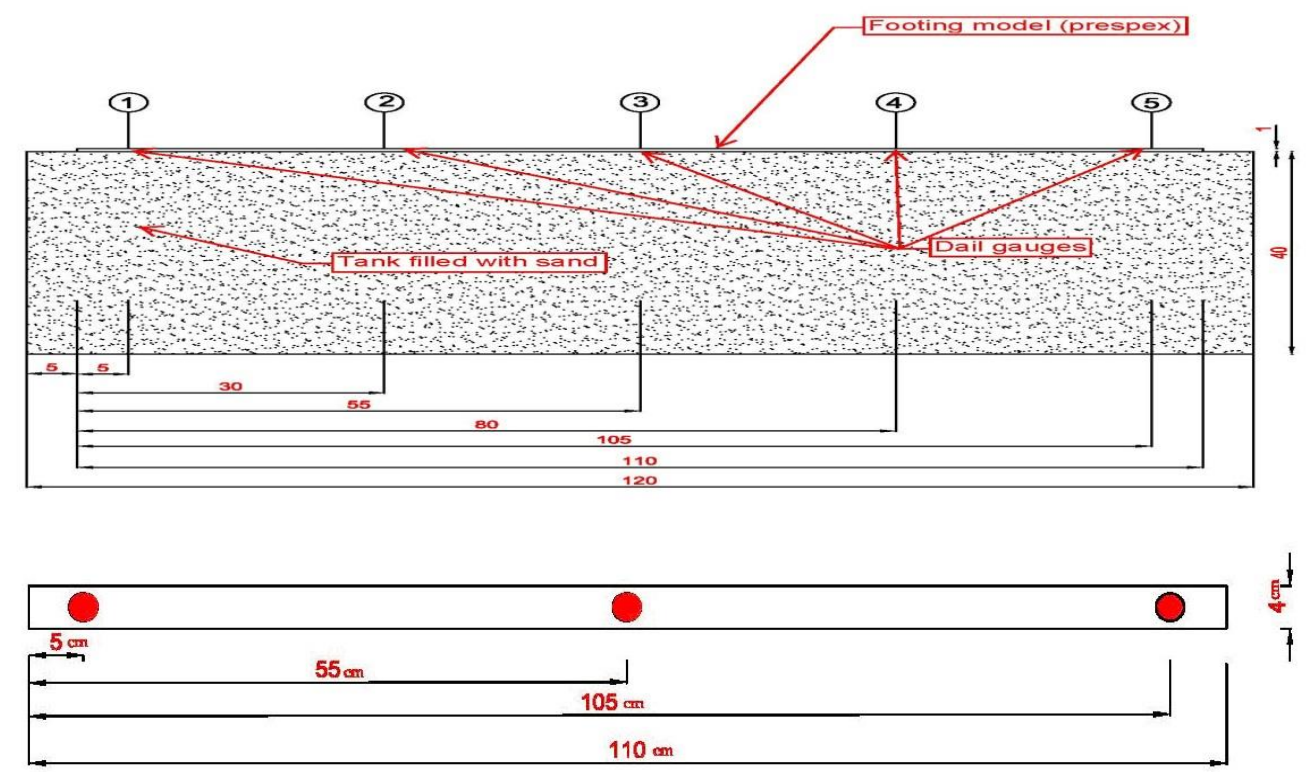

Figure 3 Cross section of the footing model

Table 2 The parameters of the test program

\begin{tabular}{|c|c|c|c|c|c|c|}
\hline Group & $\begin{array}{c}\text { Width of } \\
\text { footing } \\
(\mathrm{cm})\end{array}$ & $\begin{array}{c}\text { Thick. of } \\
\text { footing } \\
\text { (cm) }\end{array}$ & Soil type & $\begin{array}{c}\text { Dry } \\
\text { density } \\
(\mathbf{t} / \mathbf{m} 3)\end{array}$ & $\begin{array}{c}\text { Elastic } \\
\text { modulus } \\
\left(\mathrm{kg} / \mathrm{cm}^{2}\right)\end{array}$ & $\begin{array}{l}\text { Load (P) } \\
\quad(\mathbf{k g})\end{array}$ \\
\hline \multirow{3}{*}{1} & 4 & 0.8 & \multirow{3}{*}{ A } & 1.74 & 454.2 & $40-60-80$ \\
\hline & 4 & 1 & & 1.74 & 454.2 & $40-60-80$ \\
\hline & 4 & 1.2 & & 1.74 & 454.2 & $40-60-80$ \\
\hline \multirow{3}{*}{2} & 4 & 0.8 & \multirow{3}{*}{ B } & 1.995 & 727.4 & $40-60-80$ \\
\hline & 4 & 1 & & 1.995 & 727.4 & $40-60-80$ \\
\hline & 4 & 1.2 & & 1.995 & 727.4 & $40-60-80$ \\
\hline \multirow{3}{*}{3} & 4 & 0.8 & \multirow{3}{*}{$\mathrm{C}$} & 2.185 & 850 & $40-60-80$ \\
\hline & 4 & 1 & & 2.185 & 850 & $40-60-80$ \\
\hline & 4 & 1.2 & & 2.185 & 850 & $40-60-80$ \\
\hline
\end{tabular}

\subsection{Test Results}

Loads were applied in increments from $40 \mathrm{~kg}$ to reach $80 \mathrm{~kg}$, each load was divided into three concentrated loads, stresses of 10,15 and $20 \mathrm{t} / \mathrm{m} 2$ was developed under the concentrated loads. 
Readings of the dial gauges were taken at each increment. Figures from 4 to 12 show the settlement along the strip footing for the different soils, applied loads and thicknesses of the footings. Three various strip thickness $(\mathrm{t}=8,10$ and $12 \mathrm{~mm})$ and three types of soil (A, B and C) were studied under three stages of loadings (40, 60 and $80 \mathrm{Kg}$ ).

It can be noticed that settlement tends to concentrate under the point where loads act on the flexible foundations. As the thickness of the footing increases the settlement decreases. That is shown especially at the loaded points. However, the unloaded points are subjected to disturbance causing reversed behavior. Figures from 13 to 15 show the effect of changing the soil stiffness on the performance of the strip footing. It shows that increasing the soil stiffness decreases the corresponding settlement.

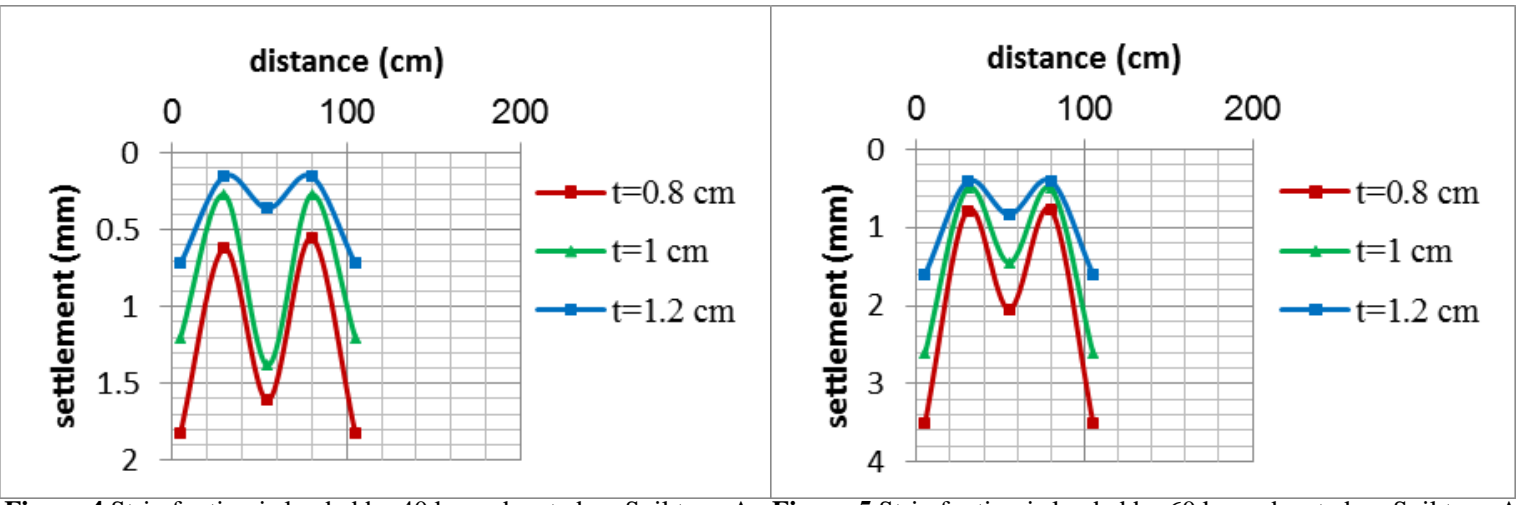

Figure 4 Strip footing is loaded by $40 \mathrm{~kg}$ and rested on Soil type A Figure 5 Strip footing is loaded by $60 \mathrm{~kg}$ and rested on Soil type A

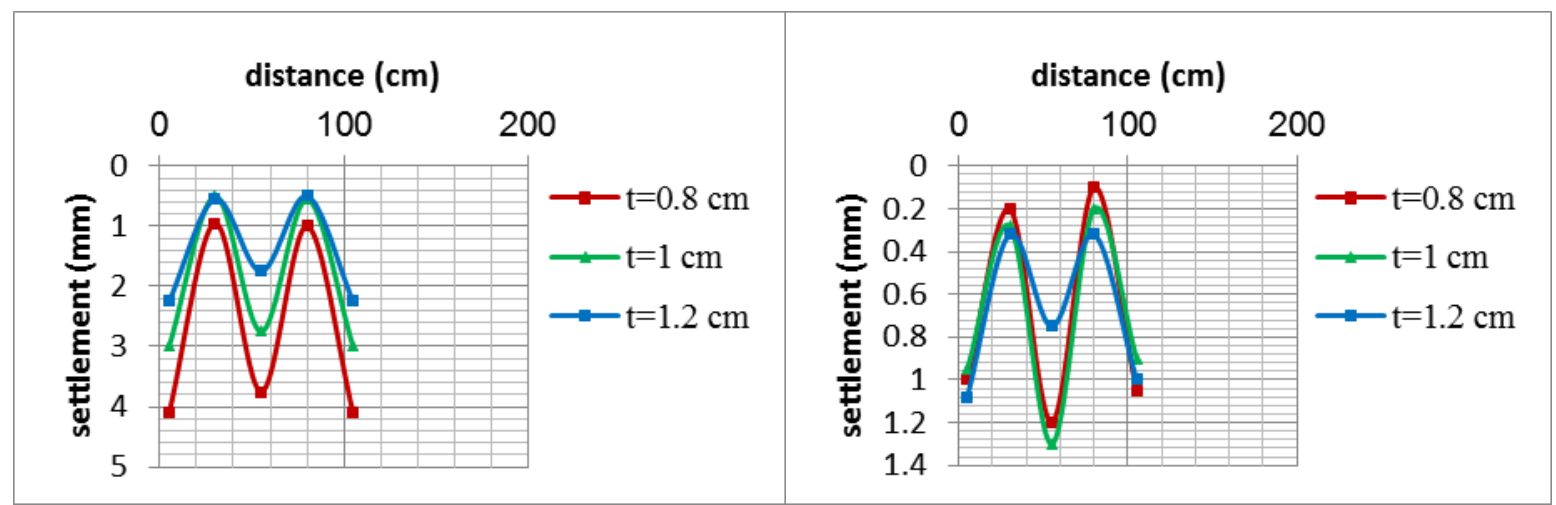

Figure 6 Strip footing is loaded by $80 \mathrm{~kg}$ And rested on Soil type A Figure 7 Strip footing is loaded by $40 \mathrm{~kg}$ And rested on Soil type B

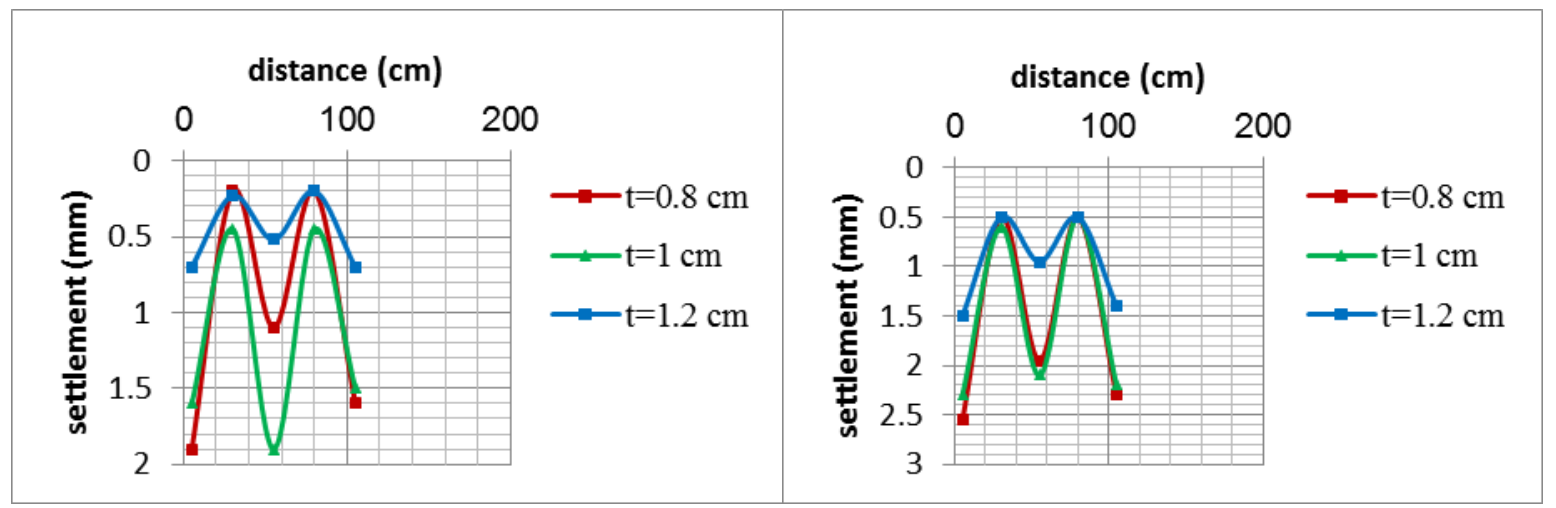

Figure 8 Strip footing is loaded by $60 \mathrm{~kg}$ And rested on Soil type B Figure 9 Strip footing is loaded by $80 \mathrm{~kg}$ And rested on Soil type B 


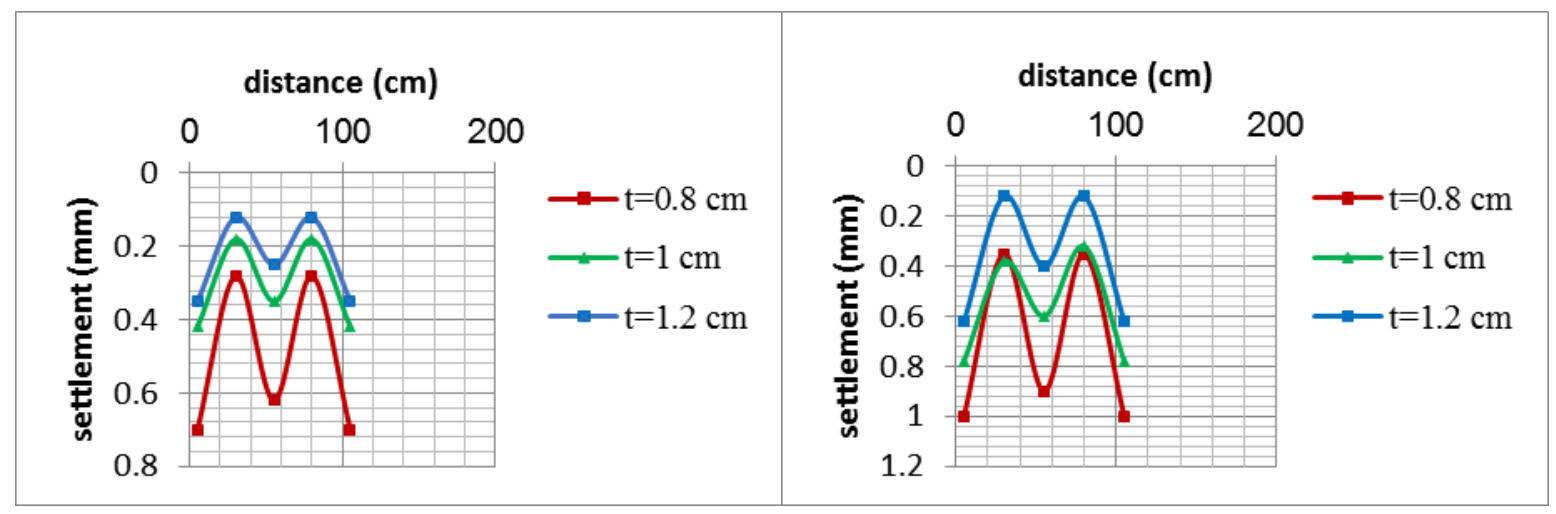

Figure 10 Strip footing is loaded by $40 \mathrm{~kg}$ And rested on Soil type C Figure 11 Strip footing is loaded by $60 \mathrm{~kg}$ And rested on Soil type C

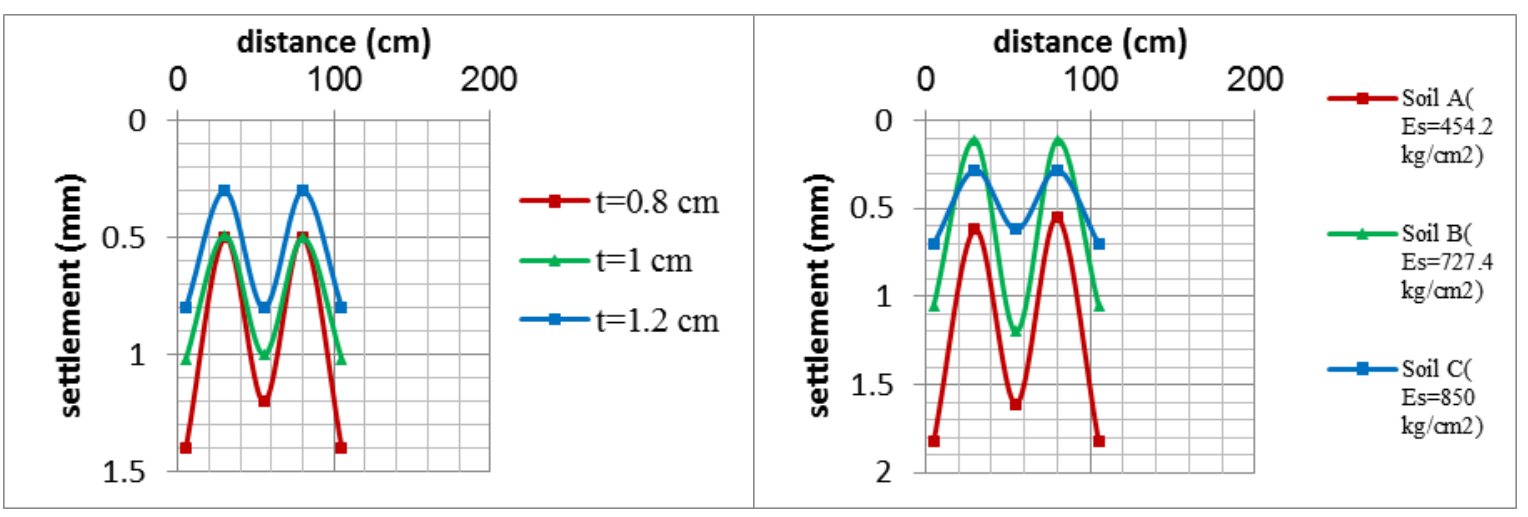

Figure 12 Strip footing is loaded by $80 \mathrm{~kg}$ And rested on Soil type C Figure 13 Strip footing is loaded by $40 \mathrm{~kg}$ for thickness $8 \mathrm{~mm}$

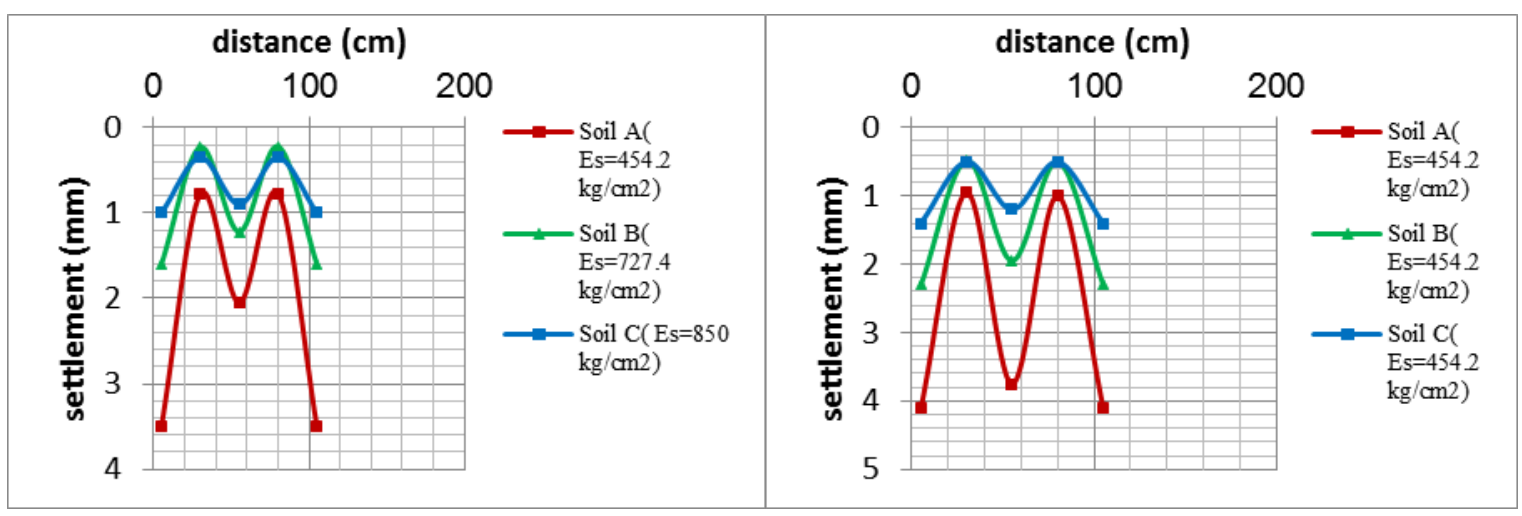

Figure 14 Strip footing is loaded by $60 \mathrm{~kg}$ for thickness $8 \mathrm{~mm}$ Figure 15 Strip footing is loaded by $40 \mathrm{~kg}$ for thickness $8 \mathrm{~mm}$

\section{FINITE ELEMENT ANALYSIS}

In order to compare the experimental results with the finite element analysis, the footing dimensions for the finite element model were the same as the experimental model. The dimensions were width $4 \mathrm{~cm}$, length $110 \mathrm{~cm}$ and width 8,10 and $12 \mathrm{~mm}$. Two types of loading were examined to give the same final load, the first was a series of three point loads, same as performed in the experimental work and the second was a uniform line load along the length of the strip footing. The soil parameters for the compacted fill are listed in Table3. Figure 16 shows the boundary of the model and Figure 17 shows the disturbance plane for the concentrated loading. 


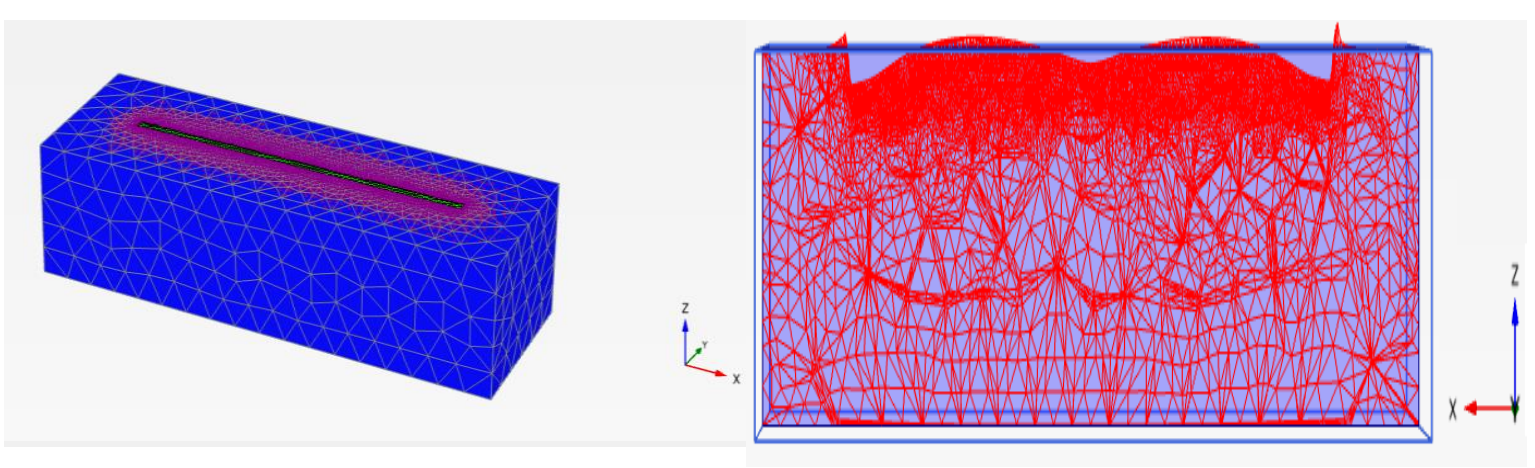

Figure 16 The Boundary of 3D-Model

Figure 17 The disturbance Plane

Table 3 The parameters of Finite element model

\begin{tabular}{|c|c|c|c|c|c|c|c|}
\hline Group & $\begin{array}{l}\text { Load } \\
\text { Type }\end{array}$ & $\begin{array}{l}\text { Width } \\
\text { (cm) }\end{array}$ & $\begin{array}{l}\text { Thick. } \\
\text { (cm) }\end{array}$ & Soil type & \multicolumn{2}{|c|}{ Soil Stiffness $\left(\mathrm{Kg} / \mathrm{cm}^{2}\right)$} & $\operatorname{Load}(P)$ \\
\hline \multirow{3}{*}{1} & \multirow{3}{*}{$\begin{array}{l}\text { Point Load } \\
\text { and } \\
\text { Line Load }\end{array}$} & 4 & 0.8 & \multirow{3}{*}{ A } & $E_{\text {oed }}^{\text {ref }}$ & 454.20 & 60 \\
\hline & & 4 & 1 & & $E_{\text {oed }}^{\text {ref }}$ & 454.2 & 60 \\
\hline & & 4 & 1.2 & & $E_{\text {oed }}^{\text {ref }}$ & 1363 & 60 \\
\hline \multirow{3}{*}{2} & \multirow{3}{*}{$\begin{array}{l}\text { Point Load } \\
\text { and } \\
\text { Line Load }\end{array}$} & 4 & 0.8 & \multirow{3}{*}{ B } & $E_{\text {oed }}^{\text {ref }}$ & 727.4 & 60 \\
\hline & & 4 & 1 & & $E_{\text {oed }}^{\text {ref }}$ & 727.4 & 60 \\
\hline & & 4 & 1.2 & & $E_{\text {oed }}^{\text {ref }}$ & 2182 & 60 \\
\hline \multirow{3}{*}{3} & \multirow{3}{*}{$\begin{array}{l}\text { Point Load } \\
\text { and } \\
\text { Line Load }\end{array}$} & 4 & 0.8 & \multirow{3}{*}{$\mathrm{C}$} & $E_{\text {oed }}^{r e f}$ & 850 & 60 \\
\hline & & 4 & 1 & & $E_{\text {oed }}^{\text {ref }}$ & 850 & 60 \\
\hline & & 4 & 1.2 & & $E_{\text {oed }}^{\text {ref }}$ & 2550 & 60 \\
\hline
\end{tabular}

\section{COMPARISONS}

Figures from 18 to 20 show a comparison between the resulted settlement values and the observed ones, for three various strip thickness $(\mathrm{t}=8,10$ and $12 \mathrm{~mm})$ and three types of soils (A, B and C). These were studied under the condition of total concentrated load equal to $60 \mathrm{~kg}$. It can be noticed that there is a good agreement between the experimental results and the predicted ones. The differences do not exceed $10 \%$.

Figures from 21 to 23 show a comparison between the settlement of the footing under a series of point loads and the settlement under a uniform load, although each comparison carried at the same conditions and under the same total loads, but the settlement along the footing decreases significantly. 
Effect of Type of Replacement fill Beneath Strip Footing on its Behavior

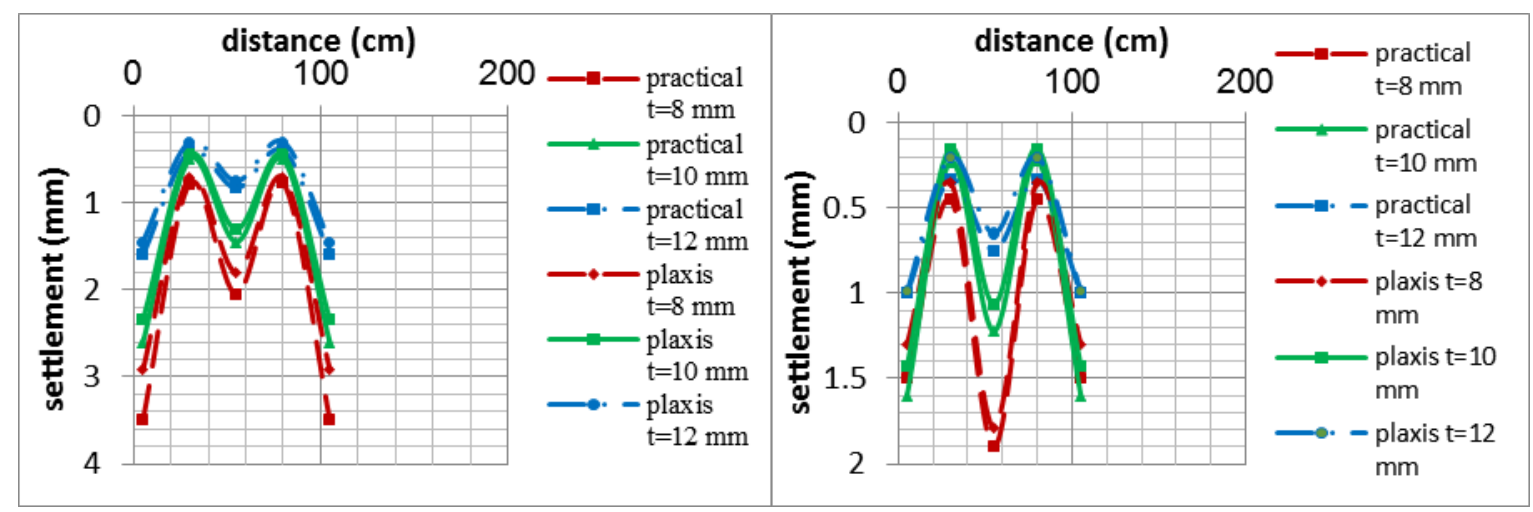

Figure 18 Calculated and observed sett. Soil A, total load of $60 \mathrm{Kg} \quad$ Figure 19 Calculated and observed sett. Soil B, total load of $60 \mathrm{Kg}$

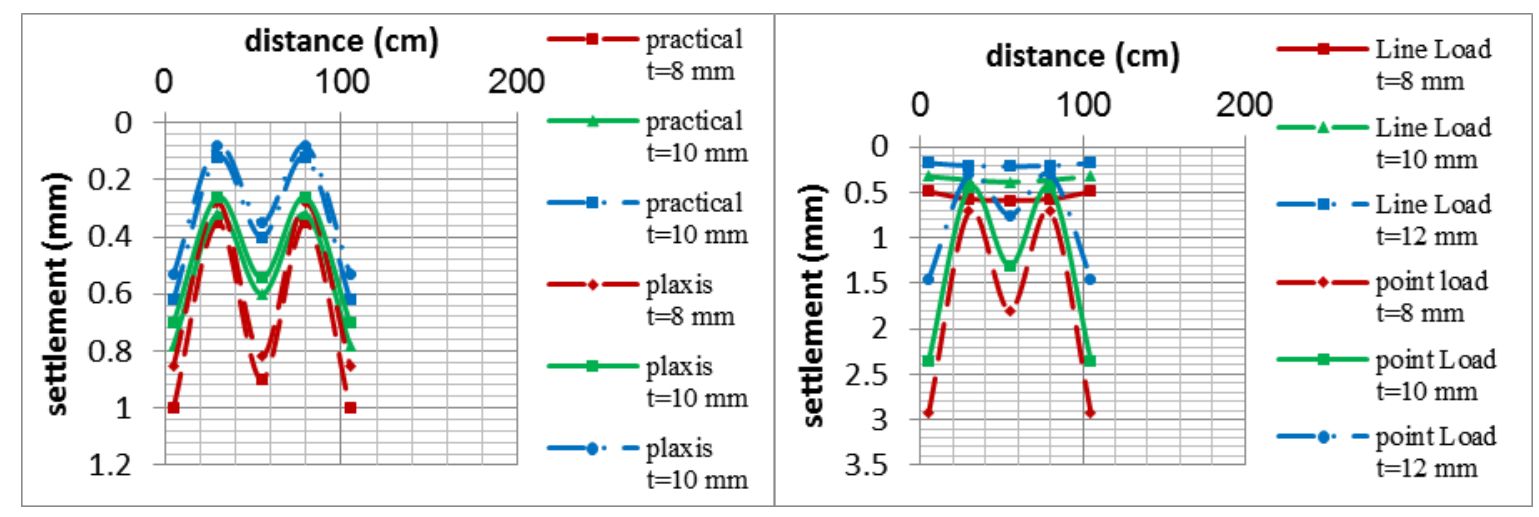

Figure 20 Calculated and observed sett. Soil C, total load of $60 \mathrm{Kg}$ Figure 21 Settlement for Point and line load conditions, Soil A, total load of $60 \mathrm{Kg}$

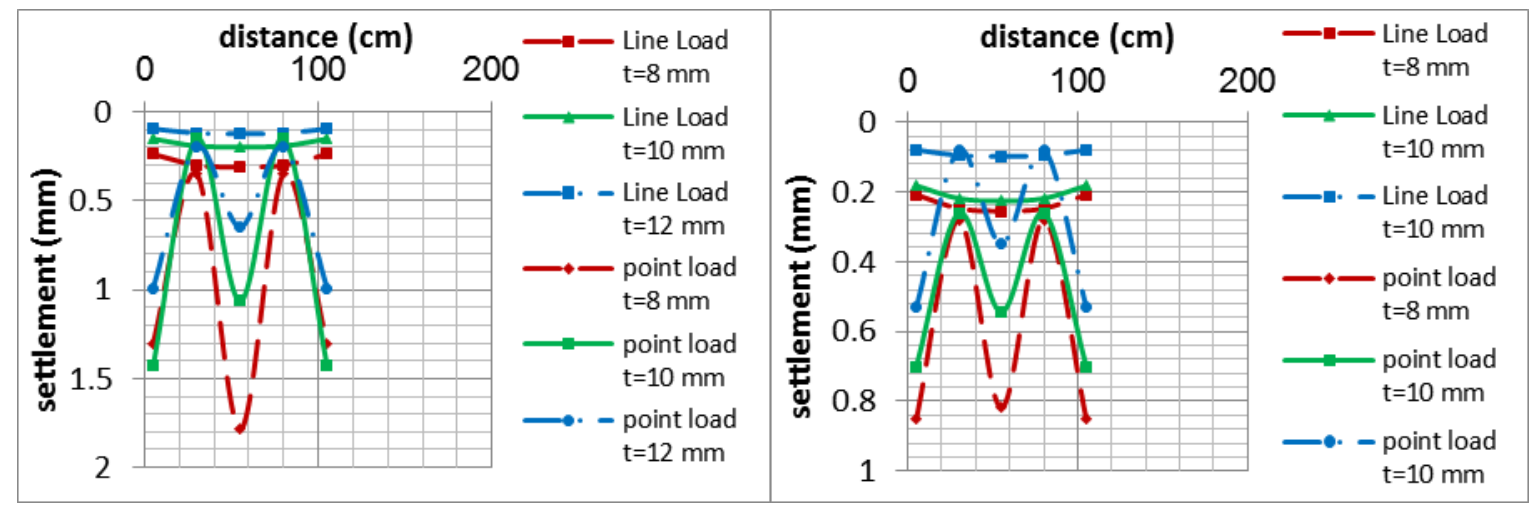

Figure 22 Settlement for Point and line load Conditions, Soil B, total load of $60 \mathrm{Kg}$ Figure 23 Settlement for Point and line load conditions, Soil C, total load of $60 \mathrm{Kg}$

\section{CONCLUSIONS}

The main conclusions of this study can be concluded as follow:

- The strip footing under a series of concentrated loads tends to behave as a series of connected isolated footings.

- Stiffness of fill strongly affects settlement values, as the stiffness of soil increases; the lower becomes its corresponding settlement value.

- For stress of $10 \mathrm{t} / \mathrm{m}^{2}$, settlement reduces by $40 \%$ in case of using fill of sand with gravel 1:2 and reduces by $25 \%$ in case of using fill of sand with grave 1:1 compared by fill of pure sand. 
- For stress of $15 \mathrm{t} / \mathrm{m}^{2}$, settlement reduces by $50 \%$ in case of using fill of sand with gravel 1:2 and reduces by $40 \%$ in case of using fill of sand with grave 1:1 compared by fill of pure sand.

- For stress of $20 \mathrm{t} / \mathrm{m}^{2}$, settlement reduces by $75 \%$ in case of using fill of sand with gravel 1:2 and reduces by $50 \%$ in case of using fill of sand with grave 1:1 compared by fill of pure sand.

- For different values of stresses and different types of fill, increasing the stiffness of the footing can reduce the values of settlement by $50 \%$.

- There is a good agreement between the experimental results and the analytical results from finite element analysis; the difference does not exceed $10 \%$.

- Changing the load condition from a series of concentrated loads to a uniform line load, reduces the settlement significantly by $80 \%$ its original value, although each comparison was carried at the same conditions of the footing and the soil.

\section{REFERENCES}

[1] Arnold, M. (1980), "Prediction of Footing Settlements on Sand", Ground Engineering, Volume 13, March, pp. 40-47.

[2] Bell, R. W., Houlsby, G. T.and Burd, H. j. (1991) "Finite element analysis of axisymmetric footings subjected to combined loads,". Proceedings of International conf. on computer Methods and Advances in Geomechanics. Caims, Australia, May 6-10, Volume 3, pp.17651770 .

[3] Hamdy, D.B. (2004). "Assessment of modulus of subgrade reaction compatible with analysis of beam on elastic foundation," Journal of the Egyptian society, Vol.15.

[4] Jeyepalan, J. K. and Boehm, R. (1986). "Procedure for predicting settlement in sands Settlement of Shallow Foundations on Cohesionless Soils: Design and Performance". ASCE, V3. PP. 1-22.

[5] Kaggwa, W. S. Cheong, M. T. and Jaksa, M. B. (2002). "Assessment of the luck associated with the settlement predictions that are based on elastic theory. Proceeding International Conference on Probabilistic in Geotechnics. Tech. and Economical Risk Estimation. Austria-New York, pp. 79-86.

[6] Lambe T.W, and Whitman, R.V.(1969) soil mechanics .john wiley \& Sons, New york.

[7] Sivakugan, N., Eckersley, J.D \& Li,H.(1998)."Settlement prediction using neural network: Australian civil.

[8] Terzaghi, K. and Peck, R. B. 1948. Soil mechanics in engineering practice. 1st Ed., J. Wiley and Sons, New York. 